\title{
The spillover effect of midwife attrition from the Nigerian midwives service scheme
}

\author{
Daniel O. Erim ${ }^{1 *}$ D, Harrison E. Offiong ${ }^{2}$, Christine Kim ${ }^{1}$, Folasade A. Bello ${ }^{3}$, Jeremy Moulton ${ }^{4}$, \\ Stephanie B. Wheeler ${ }^{1}$ and Harsha Thirumurthy ${ }^{5}$
}

\begin{abstract}
Background: The Nigerian Midwives Service Scheme (MSS) increased use of antenatal services at rural public sector clinics. However, it is unclear if women who would not have otherwise sought care, or those who would have sought care in rural private sector clinics caused this change. Additionally, it is also unclear if the reported midwife attrition was associated with a spillover of the scheme's effect on urban areas. We sought to answer these two questions using data from two nationally representative surveys.
\end{abstract}

Methods: We used an interrupted time series model to assess trends in the use of obstetric (i.e. antenatal and delivery) services among rural and urban respondents in the 2008 and 2013 Nigerian demographic and health surveys.

Results: We found that the MSS led to a 5-percentage point increase in the use of antenatal services at rural public sector clinics, corroborating findings from a previous study. This change was driven by women who would not have sought care otherwise. We also found that there was a 4-percentage point increase in the use of delivery services at urban public sector clinics, and a concurrent 4-percentage point decrease in urban home deliveries. These changes are most likely explained by midwives' attrition and exemplify a spillover of the scheme's effect.

Conclusion: Midwife attrition from the Nigerian MSS was associated with a spillover of the scheme's effect on the use of delivery services, on urban areas.

Keywords: Midwives service scheme, Maternal mortality in Nigeria, Maternal policy intervention, Midwife attrition, Policy evaluation

\section{Key messages}

Midwife attrition from the Nigerian Midwives Service Scheme was associated with greater use of delivery services in urban areas (a spillover effect).

\section{Background}

In December 2009, the Nigerian government introduced the Midwives Service Scheme (MSS) to provide greater access to obstetric services in rural areas. [1-3] The scheme was a policy response to the high maternal mortality ratio. $[4,5]$ About 2500 midwives were mobilized (from among unemployed midwives [45\%], new graduates [44\%] and retirees [11\%]) and deployed to 652 upgraded rural public

\footnotetext{
* Correspondence: erim.daniel@unc.edu

${ }^{1}$ Department of Health Policy and Management, the University of North

Carolina at Chapel Hill, Chapel Hill, NC 27599, USA

Full list of author information is available at the end of the article
}

sector clinics in all parts of the country (more to the North than the South) in July 2010. [1-4] This mobilization and deployment may have increased the pre-existing national and rural midwives' workforce by about $3 \%$ and $9 \%$ respectively (see Table 1 ), and each clinic was supposed to receive four midwives who would work in shifts to provide 24-h coverage. $[2,6]$ Despite its large scope, the scheme had a limited impact on use of obstetric services. [1-3] For instance, Okeke et al. (2016) showed that in its first year, the scheme increased use of antenatal services at rural public-sector clinics by 5 -percentage points, but had no effect on the use of delivery services at these clinics. [2,3] However, little is known about whether these changes were driven by women who would not have sought antenatal care otherwise, or by women who moved from private sector clinics (which have

(c) The Author(s). 2018 Open Access This article is distributed under the terms of the Creative Commons Attribution 4.0 International License (http://creativecommons.org/licenses/by/4.0/), which permits unrestricted use, distribution, and reproduction in any medium, provided you give appropriate credit to the original author(s) and the source, provide a link to the Creative Commons license, and indicate if changes were made. The Creative Commons Public Domain Dedication waiver (http://creativecommons.org/publicdomain/zero/1.0/) applies to the data made available in this article, unless otherwise stated. 
Table 1 A selection of demographic indices and measures of obstetric care capacity

\begin{tabular}{|c|c|c|c|}
\hline Demographic indices & National & Northern zones & Southern zones \\
\hline Population size (2006) [35] & 140 & 71 & 69 \\
\hline Number of women aged 15 - 49 years (million) $[17,35]$ & 35 & 20 & 15 \\
\hline Number of women aged 15 - 49 years in rural areas (million) $[17,35]$ & 21 & 15 & 6 \\
\hline Number of women aged 15 - 49 years in urban areas (million) $[17,35]$ & 14 & 5 & 9 \\
\hline Prevalence of pregnancy in women aged 15 - 49 years (\%) [17] & 12 & 14 & 8 \\
\hline \multicolumn{4}{|l|}{ Distribution of midwives before the Midwives Service Scheme } \\
\hline Total number of midwives $[36,37]^{a, b}$ & 89,000 & 37,000 & 52,000 \\
\hline Number of midwives in rural areas [38] ${ }^{a, b}, c$ & 30,000 & 12,000 & 18,000 \\
\hline Number of midwives in urban areas [38] ${ }^{a, b}, \mathrm{c}$ & 59,000 & 25,000 & 34,000 \\
\hline Number of midwives per 100,000 population [36] ${ }^{b}$ & 68 & 52 & 75 \\
\hline Nurses \& midwives per 100,000 population in rural public sector clinics [39] & 64 & - & - \\
\hline Nurses \& midwives per 100,000 population in rural private sector clinics [39] & 24 & - & - \\
\hline Nurses \& midwives per 100,000 population in urban public sector clinics [39] & 121 & - & - \\
\hline Nurses \& midwives per 100,000 population in urban private sector clinics [39] & 63 & - & - \\
\hline Annual number of graduating nurses and midwives [40] & 5500 & NA & NA \\
\hline \multicolumn{4}{|l|}{ Some measures of primary care clinics' capacity (rural and urban) [12] } \\
\hline Can always provide emergency obstetric care (\%) & 41 & - & - \\
\hline Can administer injectable antibiotics (\%) & 79 & - & - \\
\hline Can diagnose and treat eclampsia (\%) & 23 & - & - \\
\hline Can conduct assisted vaginal delivery (\%) & 10 & - & - \\
\hline Can diagnose and treat severe shock (\%) & 36 & - & - \\
\hline Can safely transfuse blood (\%) & 20 & - & - \\
\hline Can conduct Caesarian section (\%) & 12 & - & - \\
\hline Has at least one doctor that is constantly available (\%) & 20 & - & - \\
\hline Has at least one nurse/midwife that is constantly available (\%) & 48 & - & - \\
\hline Has at least one obstetrician that is constantly available (\%) & 8 & - & - \\
\hline Has at least one anesthesiologist that is constantly available (\%) & 7 & - & - \\
\hline Has an ambulance for transporting pregnant women to referral clinics (\%) & 5 & - & - \\
\hline Has at least one labor ward (\%) & 79 & - & - \\
\hline Has at least one delivery room (\%) & 74 & - & - \\
\hline Has at least one functional operating room (\%) & 16 & - & - \\
\hline Receives uninterrupted electricity supply whenever there are obstetric emergencies (\%) & 15 & - & - \\
\hline
\end{tabular}

NA, not applicable

a - Estimates are rounded to the nearest thousand

$\mathrm{b}$ - The zonal distribution (or densities) of midwives are plausible estimates

c - The national distribution of midwives are plausible estimates

the lowest number of midwives per capita [see Table 1] but may offer higher quality care at higher out of pocket costs]), drawn by the potentially lower healthcare cost. [7] This difference is important because women in the former group were the scheme's intended beneficiaries, and are more likely to affect maternal health indicators than those in the latter. Additionally, for various reported reasons (including irregular remuneration and unavailability of secure/decent housing), midwives started deserting their postings for more lucrative and secure urban practices in late 2010. [1-3, 8-11] While the pattern of attrition is unclear, one study suggests that by 2003, 1 in 5 deployed midwives (up to half or all in some Northern states) left the scheme. [8] However, little is known about whether midwife attrition was associated with changes in use of obstetric services in urban areas (i.e. a spillover effect). [12-14] Such information is useful to evaluators and relevant stakeholders of the scheme. We sought to answer these two questions using data from two nationally representative surveys. 


\section{Overview}

Details about the MSS are described elsewhere. [1-3] In brief, the program's goal was to drive down maternal mortality by increasing the use of obstetric services at selected rural public sector clinics. [1] This goal was to be achieved by both demand-side interventions (e.g. health education campaigns and advocacy by influential individuals in the beneficiary communities), [1-3] and supply-side interventions (e.g. mobilizing and deploying midwives to 652 upgraded rural public sector clinics, serving about half of the population in need). [4, 5] A complementary policy intervention called SURE-P MCH (Subsidy Reinvestment and Empowerment Program for Maternal and Child Health) was introduced in 2012 to cover the remaining half of the population in need. [15]

\section{Methods}

\section{The data}

We used data from the 2008 and 2013 Nigerian Demographic and Health Surveys (NDHS). [16, 17] Survey respondents (women aged 15 - 49 years) were randomly selected by probability sampling. [18] The datasets contain information on respondents' socio-demographic characteristics (e.g. age, level of education and rural/ urban residence), and use of obstetric services going back six years (i.e. 2003 - 2008 and 2008 - 2013 in the 2008 and 2013 DHS respectively). [18] We combined both 2008 and 2013 datasets to have adequate pre- and post-implementation data, and focused on the most recent birth to minimize recall bias. We also excluded respondents without a birthing experience and those that delivered in 2012 and 2013 (because of SURE-P MCH).

\section{Identification strategy}

DHS staff designated respondents' residences as rural or urban. Identifying DHS questions and their responses are presented in Table 2. Eligible respondents reported which obstetric (i.e. antenatal and delivery) service they used during their most recent pregnancy. We used these data to create our binary outcome variables, which are as follows:

Table 2 Relevant DHS questions used in this analysis

\begin{tabular}{|c|c|c|}
\hline & DHS questions & Responses \\
\hline 1 & Where did you receive antenatal care for this pregnancy? & $\begin{array}{l}\text { Home } \\
\text { - your home } \\
\text { - other home } \\
\text { Public sector } \\
\text { - Government hospital } \\
\text { - Government health center } \\
\text { - Government health post/ } \\
\text { dispensary } \\
\text { - Other public sector (site) } \\
\text { Private med. Sector } \\
\text { - Private hospital/clinic } \\
\text { - Other private med. Sector } \\
\text { Other }\end{array}$ \\
\hline 2. & How many times did you receive antenatal care during this pregnancy? & Number of times/Don't know \\
\hline 3. & Where did you give birth? & $\begin{array}{l}\text { Home } \\
\text { - your home } \\
\text { - other home } \\
\text { Public sector } \\
\text { - Government hospital } \\
\text { - Government health center } \\
\text { - Government health post/ } \\
\text { dispensary } \\
\text { - Other public sector site } \\
\text { Private med. Sector } \\
\text { - Private hospital/clinic } \\
\text { - Other private med. Sector } \\
\text { Other }\end{array}$ \\
\hline 4. & \multicolumn{2}{|c|}{$\begin{array}{l}\text { Many different factors can prevent women from getting medical advice or treatment for themselves. } \\
\text { When you are sick and want to get medical advice or treatment, is each of the following a big problem or } \\
\text { not? }\end{array}$} \\
\hline & - Getting permission to go to the doctor? & Big problem or not a big problem \\
\hline & - The distance to the health facility? & Big problem or not a big problem \\
\hline & - Not wanting to go alone? & Big problem or not a big problem \\
\hline & - Attitude of the health workers? & Big problem or not a big problem \\
\hline
\end{tabular}


Table 3 A comparison of dependent and independent variables for rural and urban respondents in the pre- and post-intervention groups

\begin{tabular}{|c|c|c|c|c|c|c|c|c|}
\hline \multirow{2}{*}{$\overline{\text { Characteristics }}$} & \multicolumn{4}{|c|}{ Rural respondents } & \multicolumn{4}{|c|}{ Urban respondents } \\
\hline & $\begin{array}{l}\text { Last childbirth } \\
\text { occurred before } \\
2010\end{array}$ & $\begin{array}{l}\text { Last childbirth } \\
\text { occurred between } \\
2010 \text { - } 2011\end{array}$ & Difference & $\begin{array}{l}\text { T-test } \\
p \text { - } \\
\text { value }\end{array}$ & $\begin{array}{l}\text { Last childbirth } \\
\text { occurred before } \\
2010\end{array}$ & $\begin{array}{l}\text { Last childbirth } \\
\text { occurred between } \\
2010-2011\end{array}$ & Difference & $\begin{array}{l}\text { T-test } \\
p \text { - } \\
\text { value }\end{array}$ \\
\hline Mean age (years) & 29.9 & 28.5 & -1.4 & $\begin{array}{l}< \\
0.001\end{array}$ & 30.9 & 29.7 & -1.2 & $\begin{array}{l}< \\
0.001\end{array}$ \\
\hline $\begin{array}{l}\text { Average number of children } \\
\text { ever born }\end{array}$ & 4.4 & 4.2 & -0.2 & $\begin{array}{l}< \\
0.001\end{array}$ & 3.9 & 3.6 & -0.3 & $\begin{array}{l}< \\
0.001\end{array}$ \\
\hline $\begin{array}{l}\text { Mean number of years of } \\
\text { formal education received }\end{array}$ & 3.4 & 3.4 & 0.0 & $\begin{array}{l}< \\
0.956\end{array}$ & 7.4 & 8.1 & +0.7 & $\begin{array}{l}< \\
0.001\end{array}$ \\
\hline $\begin{array}{l}\text { Percentage in the middle or } \\
\text { a lower wealth quintile }\end{array}$ & 83.3 & 84.0 & 0.7 & 0.128 & 28.4 & 27.9 & -0.5 & 0.532 \\
\hline \multicolumn{9}{|l|}{ Other characteristics } \\
\hline $\begin{array}{l}\text { Any antenatal visit to } \\
\text { public-sector clinics (\%) }\end{array}$ & 36.1 & 45.5 & +9.4 & $\begin{array}{l}< \\
0.001\end{array}$ & 54.4 & 59.6 & +5.2 & $\begin{array}{l}< \\
0.001\end{array}$ \\
\hline $\begin{array}{l}\text { Any antenatal visit to } \\
\text { private clinics (\%) }\end{array}$ & 9.2 & 7.6 & -1.6 & $\begin{array}{l}< \\
0.001\end{array}$ & 26.6 & 26.6 & 0.0 & 0.982 \\
\hline $\begin{array}{l}\text { Antenatal visits to other } \\
\text { sites/No antenatal care }\end{array}$ & 52.8 & 46.3 & -6.5 & $\begin{array}{l}< \\
0.001\end{array}$ & 18.3 & 13.4 & -4.9 & $\begin{array}{l}< \\
0.001\end{array}$ \\
\hline $\begin{array}{l}\text { Deliveries in public-sector } \\
\text { clinics/hospitals (\%) }\end{array}$ & 16.3 & 18.0 & +1.7 & $\begin{array}{l}< \\
0.001\end{array}$ & 34.9 & 39.1 & $+4.3 \%$ & $\begin{array}{l}< \\
0.001\end{array}$ \\
\hline $\begin{array}{l}\text { Deliveries in private-sector } \\
\text { clinics/hospitals (\%) }\end{array}$ & 7.9 & 6.3 & -0.16 & $\begin{array}{l}< \\
0.001\end{array}$ & 24.4 & 25.6 & +1.1 & 0.162 \\
\hline Deliveries at home (\%) & 74.7 & 75.4 & +0.7 & 0.208 & 37.9 & 35.0 & -2.9 & 0.001 \\
\hline \multicolumn{9}{|c|}{ Barriers to accessing primary healthcare services } \\
\hline $\begin{array}{l}\text {-those in need of } \\
\text { permission (\%) }\end{array}$ & 16.4 & 14.7 & -1.7 & $\begin{array}{l}< \\
0.001\end{array}$ & 11.4 & 6.7 & -4.7 & $\begin{array}{l}< \\
0.001\end{array}$ \\
\hline $\begin{array}{l}\text {-those who couldn't } \\
\text { afford the cost of care (\%) }\end{array}$ & 63.3 & 52.1 & -11.2 & $\begin{array}{l}< \\
0.001\end{array}$ & 43.1 & 33.1 & -10.0 & $\begin{array}{l}< \\
0.001\end{array}$ \\
\hline $\begin{array}{l}\text {-those who thought the } \\
\text { closest clinic/hospital was } \\
\text { too far (\%) }\end{array}$ & 46.2 & 40.0 & -6.3 & $\begin{array}{l}< \\
0.001\end{array}$ & 20.5 & 15.7 & -4.8 & $\begin{array}{l}< \\
0.001\end{array}$ \\
\hline $\begin{array}{l}\text {-those in need of } \\
\text { company (\%) }\end{array}$ & 21.2 & 18.1 & -3.1 & $\begin{array}{l}< \\
0.001\end{array}$ & 9.6 & 7.0 & -2.6 & $\begin{array}{l}< \\
0.001\end{array}$ \\
\hline Number of observations & 15,495 & 11,806 & - & - & 6224 & 5737 & - & - \\
\hline
\end{tabular}

The pre- and post-intervention groups made up of respondents whose most-recent birth occurred between 2003 and 2009 and 2010 - 2013 respectively. In the difference column, " + " indicates an increase, while "-" indicates a decrease. The significant reduction in barriers to accessing primary healthcare services over time may be a consequence of the MSS, or may mediate the effect of the scheme. However, we chose to leave them in the models to avoid omitted variable bias, and because our conclusions were robust to their exclusion

1. Use of antenatal services:

a. one or more antenatal visits to public-sector clinics;

b. one or more antenatal visits to private-sector clinics;

c. non-use of antenatal services (including those who reported "home" or "other" as sites of antenatal care)

2. Use of delivery services:
a. Delivered at a public-sector clinic;
b. Delivered at a private-sector clinic;
c. Delivered at home/other sites.

Thus, we had six outcome variables, which allowed us to keep track of the "origin" of those who drove noticeable changes in obstetric care utilization trends.

\section{Analytic approach}

We made the following assumptions: that there was no other large-scale intervention to increase demand for obstetric services; [1-3] that selected public sector clinics were in rural communities with severely limited access to obstetric care; $[1-3,9]$ and that pregnant women seek obstetric care at sites close to where they reside. [12-14, 19] We used an interrupted time series (ITS) model to specify trends and assess for changes in use of obstetric services during the pre- and postimplementation periods (i.e. 2003 - 2009 and $2010-$ 2011 respectively). This model relies on the assumption that respondents did not select into either of these periods. [2, 3] It also allows us to "sort" eligible 
Table 4 The estimated intention to treat effect (ITTE) of the MSS on rural respondents

\begin{tabular}{|c|c|c|c|c|c|c|}
\hline \multirow[t]{2}{*}{ Outcomes } & \multicolumn{3}{|l|}{ Antenatal visits } & \multicolumn{3}{|l|}{ Delivery sites } \\
\hline & Public sector clinics & Private sector clinics & No antenatal care & Public sector clinics & Private sector clinics & Home \\
\hline \multicolumn{7}{|l|}{ National } \\
\hline \multirow[t]{2}{*}{ Effect in 2010} & $0.050^{* * *}$ & -0.002 & $-0.051^{* * *}$ & 0.016 & 0.002 & -0.013 \\
\hline & $(0.016)$ & $(0.006)$ & $(0.011)$ & $(0.011)$ & $(0.008)$ & $(0.008)$ \\
\hline \multirow[t]{2}{*}{ Pre-MSS trend } & 0.001 & -0.001 & -0.003 & 0.002 & -0.001 & -0.001 \\
\hline & $(0.003)$ & $(0.002)$ & $(0.007)$ & $(0.002)$ & $(0.001)$ & $(0.004)$ \\
\hline Observations & 25,562 & 25,065 & 26,059 & 26,328 & 26,401 & 26,401 \\
\hline R-squared & 0.211 & 0.211 & 0.338 & 0.195 & 0.216 & 0.376 \\
\hline \multicolumn{7}{|l|}{ Northern zones } \\
\hline \multirow[t]{2}{*}{ Effect in 2010} & $0.053^{* * *}$ & 0.003 & $-0.056^{* *}$ & 0.010 & 0.008 & -0.016 \\
\hline & $(0.003)$ & $(0.003)$ & $(0.007)$ & $(0.006)$ & $(0.007)$ & $(0.014)$ \\
\hline \multirow[t]{2}{*}{ Pre-MSS trend } & 0.009 & 0.0008 & -0.009 & $0.006^{*}$ & -0.001 & -0.006 \\
\hline & $(0.011)$ & $(0.001)$ & $(0.009)$ & $(0.002)$ & $(0.001)$ & $(0.002)$ \\
\hline Observations & 19,100 & 19,100 & 19,474 & 19,777 & 19,777 & 19,777 \\
\hline R-squared & 0.251 & 0.156 & 0.316 & 0.161 & 0.158 & 0.273 \\
\hline \multicolumn{7}{|l|}{ Southern zones } \\
\hline \multirow[t]{2}{*}{ Effect in 2010} & 0.039 & -0.018 & -0.026 & 0.034 & -0.021 & 0.004 \\
\hline & $(0.045)$ & $(0.017)$ & $(0.035)$ & $(0.030)$ & $(0.020)$ & $(0.002)$ \\
\hline \multirow[t]{2}{*}{ Pre-MSS trend } & -0.004 & -0.002 & 0.011 & -0.008 & -0.001 & $0.011^{*}$ \\
\hline & $(0.007)$ & $(0.007)$ & $(0.022)$ & $(0.006)$ & $(0.005)$ & $(0.004)$ \\
\hline Observations & 5965 & 5965 & 6585 & 6624 & 6624 & 6624 \\
\hline R-squared & 0.127 & 0.164 & 0.244 & 0.124 & 0.159 & 0.289 \\
\hline
\end{tabular}

Robust standard errors are in parentheses. ${ }^{* * *} p<0.01,{ }^{* *} p<0.05,{ }^{*} p<0.1$ Pre-MSS trend, pre-implementation trend (i.e. the trend in the indicated outcome prior to implementation of the midwives service scheme)

respondents by their delivery year, which makes trends in use of obstetric services more obvious. Our first step was to use the ITS model to assess trends in use of obstetric services among rural respondents. We did this to validate our approach, and to see where those who drove the increase in use of antenatal services were coming from (i.e. private sector clinics or non-use/home). [2, 3] Next, we used the ITS model to assess trends in use of obstetric services among urban respondents. Under the null hypothesis, there should be no changes. Our model specification is as follows:

$Y=\alpha+\beta_{1}\left(\right.$ Year $\left._{i}-2010\right)+\beta_{2} *\left(\right.$ Year $\left._{i} \geq 2010\right) *\left(\right.$ Year $_{i}-$ $2010)+\beta_{3} *\left(\right.$ Year $\left._{i} \geq 2010\right)+X_{i}+\varepsilon_{i}$.

$Y$ is the outcome variable, and represents any of the six binary indicators of use of obstetric services $(1 \mathrm{a}-1 \mathrm{c}$ and $2 \mathrm{a}-2 \mathrm{c}$ above) for each respondent. $\alpha$ is the constant term, and Year ${ }_{i}$ represents the year of most recent birth, re-centered around year 2010 for each respondent. The coefficient of this re-centered variable $\left(\beta_{1}\right)$ captures the indicated trend in use of obstetric services. We included this re-centered variable interacted with an indicator of the pre- and post-implementation periods. Its coefficient $\left(\beta_{2}\right)$ represents the difference between the pre- and post-implementation trend in use of obstetric services. $\beta_{3}$ measures the size of the vertical distance between both pre- and post-implementation trends in 2010 and thus estimates the program's intention-to-treat effect (ITTE, for rural respondents) and spillover effect (for urban respondents). Our control variables included respondents' years of formal education, wealth quintile, reported barriers to accessing care (see Table 2 - item 4, all captured as binary variables), and state fixed-effects (to minimize bias from state-level variation in government subsidies for usual out-of-pocket obstetric care costs [at select public-sector clinics] on access to obstetric care). $\varepsilon_{i}$ represents the error term. We used survey sampling weights in our regression models, and clustered observations by geopolitical zones (informed by variations in the allocation of MSS resources). $[1,2]$ As in Okeke et al.'s [2016] study, [2, 3] we conducted national- and regional-level (Northern and Southern regions) analyses. We conducted regional-level analyses because we were concerned about potentially larger effect sizes in the North (it had more deployed midwives and MSS clinics and a higher attrition rate than in the South) or in the south (due to the likelihood for greater uptake of obstetric care services than in the North). [16, 17, 20, 21] 


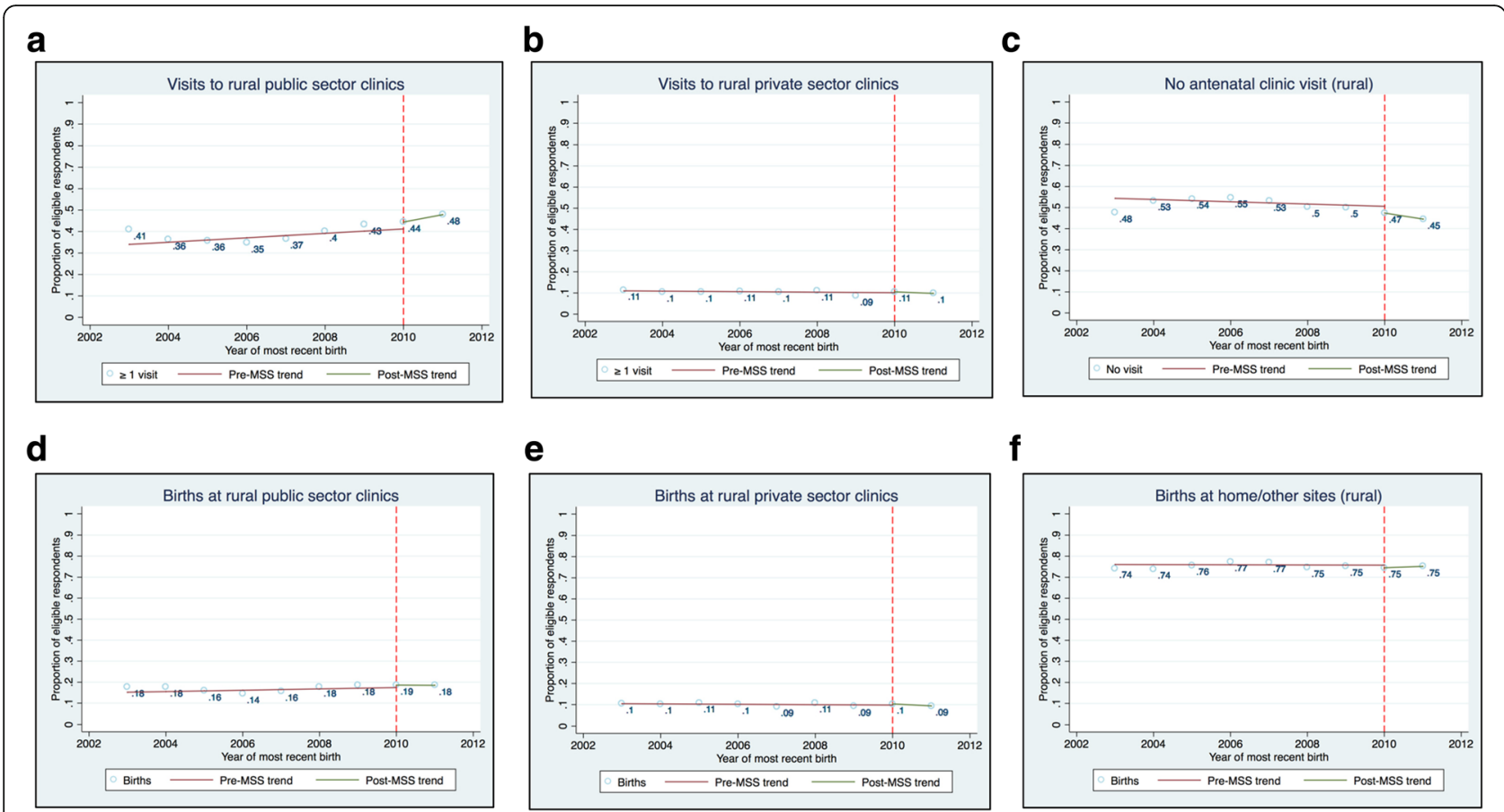

Fig. 1 Changes in obstetric care utilization in rural areas

\section{Results}

\section{Characteristics of the sample}

Respondents' characteristics are presented in Table 3. Urban respondents were about a third of the sample. Compared to rural respondents, urban respondents a) had more years of formal education, b) had fewer children, c) were more likely to use obstetric care services d) were less likely to be in the middle or a lower wealth quintile, and e) were less likely to report barriers to accessing primary care. The table also contains the size and significance of unadjusted differences in the means of relevant individual-level characteristics between rural and urban respondents' pre- and post-implementation groups. Regional level characteristics are not presented.

\section{Effect on rural respondents}

Our estimates of the scheme's ITTE are presented in Table 4. At the national level, the MSS increased antenatal visits to public-sector clinics by 5 percentage points ( $p$-value $=0.001)$ in 2010 . This change was accompanied by a 5 percentage points decline (p-value $=0$. 006) in non-use of antenatal care services in the same year. We found no evidence of any change in use of antenatal services at private-sector clinics. We also found no evidence of any change in the use of delivery services. Trends in the use of obstetric services among rural respondents are presented in Fig. 1.

In the Northern region, there was a 5.3 percentage point increase $(p$-value $=0.003)$ in antenatal visits to public sector clinics. This change was also accompanied by a 5.6 percentage point decline $(p$-value $=0.016)$ in non-use of antenatal care services in the same year. We found no evidence of any change in use of obstetric care services at Northern private-sector clinics. We also found no evidence of any change in the use of obstetric care services in the southern zones.

\section{Spillover effects}

Our estimates of the program's spillover effects are presented in Table 5. At the national level, we found no evidence of any change in use of antenatal services at urban public sector clinics, and a 4 percentage points increase $(p$-value $=0.041)$ in the use of delivery services at urban public sector clinics. We also found no evidence of any change in the use of obstetric services at urban private sector clinics. Trends in the use of obstetric services among urban respondents are presented in Fig. 2.

In the Northern region, there was a 5.4 percentage point increase $(\mathrm{p}$-value $=0.011)$ in the use of delivery services at public sector clinics and a concurrent 4 percentage point decrease ( $\mathrm{p}$-value $=0.075$ ) in home births in 2010. We found no evidence of any change in other outcomes in the Northern region. Similarly, we found no evidence of any change in the use of obstetric services among urban respondents in the south of the country. 
Table $\mathbf{5}$ The estimated "spillover" effect of the MSS on urban respondents

\begin{tabular}{|c|c|c|c|c|c|c|}
\hline \multirow[t]{2}{*}{ Outcomes } & \multicolumn{3}{|c|}{ Antenatal visits } & \multicolumn{3}{|l|}{ Delivery sites } \\
\hline & $\begin{array}{l}\text { Public sector } \\
\text { clinics }\end{array}$ & $\begin{array}{l}\text { Private sector } \\
\text { clinics }\end{array}$ & $\begin{array}{l}\text { Other sites/no antenatal } \\
\text { care }\end{array}$ & $\begin{array}{l}\text { Public sector } \\
\text { clinics }\end{array}$ & $\begin{array}{l}\text { Private sector } \\
\text { clinics }\end{array}$ & $\begin{array}{l}\text { Other sites/ } \\
\text { home }\end{array}$ \\
\hline \multirow{2}{*}{$\begin{array}{l}\text { Spillover } \\
\text { effect }\end{array}$} & 0.017 & -0.004 & -0.011 & $0.041^{* *}$ & -0.009 & -0.020 \\
\hline & $(0.026)$ & $(0.015)$ & $(0.011)$ & $(0.015)$ & $(0.010)$ & $(0.014)$ \\
\hline \multirow[t]{2}{*}{ Pre-MSS trend } & 0.003 & 0.001 & -0.004 & -0.003 & 0.004 & 0.004 \\
\hline & $(0.006)$ & $(0.005)$ & $(0.004)$ & $(0.005)$ & $(0.004)$ & $(0.006)$ \\
\hline Observations & 10,660 & 10,660 & 11,374 & 11,516 & 11,516 & 11,516 \\
\hline R-squared & 0.158 & 0.250 & 0.197 & 0.120 & 0.246 & 0.362 \\
\hline \multicolumn{7}{|l|}{ Northern region } \\
\hline \multirow{2}{*}{$\begin{array}{l}\text { Spillover } \\
\text { effect }\end{array}$} & 0.027 & -0.019 & -0.003 & $0.054^{* *}$ & -0.015 & $-0.044^{*}$ \\
\hline & $(0.028)$ & $(0.013)$ & $(0.014)$ & $(0.006)$ & $(0.006)$ & $(0.013)$ \\
\hline \multirow[t]{2}{*}{ Pre-MSS trend } & -0.003 & 0.005 & -0.0028 & -0.008 & 0.008 & 0.004 \\
\hline & $(0.008)$ & $(0.008)$ & $(0.006)$ & $(0.004)$ & $(0.007)$ & $(0.008)$ \\
\hline Observations & 5163 & 5163 & 5404 & 5514 & 5514 & 5514 \\
\hline R-squared & 0.116 & 0.164 & 0.226 & 0.166 & 0.188 & 0.357 \\
\hline \multicolumn{7}{|c|}{ Southern region } \\
\hline \multirow{2}{*}{$\begin{array}{l}\text { Spillover } \\
\text { effect }\end{array}$} & 0.001 & 0.011 & -0.014 & 0.018 & 0.002 & 0.008 \\
\hline & $(0.053)$ & $(0.030)$ & $(0.019)$ & $(0.031)$ & $(0.018)$ & $(0.016)$ \\
\hline \multirow[t]{2}{*}{ Pre-MSS trend } & 0.009 & -0.002 & -0.005 & 0.001 & -0.001 & 0.005 \\
\hline & $(0.012)$ & $(0.009)$ & $(0.007)$ & $(0.010)$ & $(0.003)$ & $(0.009)$ \\
\hline Observations & 5497 & 5497 & 5970 & 6002 & 6002 & 6002 \\
\hline R-squared & 0.133 & 0.145 & 0.120 & 0.092 & 0.145 & 0.181 \\
\hline
\end{tabular}

Robust standard errors are in parentheses. ${ }^{* * *} p<0.01,{ }^{* *} p<0.05,{ }^{*} p<0.1$ Pre-MSS trend, pre-implementation trend (i.e. the trend in the indicated outcome prior to implementation of the midwives service scheme)

\section{Discussion}

We set out to gain more insight into mechanisms underlying reported MSS-induced changes in the antenatal clinic visits to rural public sector clinics and to determine if midwives' attrition was associated with a spillover of the scheme's effect into urban areas. In achieving the first goal, we obtained effect sizes that are identical to those in Okeke et al.'s (2016) study, [2,3] and demonstrated that the reported increase in antenatal clinic visits to rural public sector clinics was driven by the program's intended beneficiaries. Our results also suggest that women who sought care in private sector clinics $(<8 \%$ of women aged $15-50$ years) were not attracted by the increased provider availability, reduced waiting time or potentially lower out of pocket cost of care at public sector clinics. [8] As previously demonstrated, the MSS-induced increase in antenatal clinic visits to rural public sector clinics was significant and larger in the northern region than the southern region. [1-3] Regarding our second goal, we demonstrated that in 2010, Northern urban public sector clinics witnessed no change in the use of antenatal services, but saw an increase in the use of delivery services.
This increase was driven by women who would have otherwise delivered at home.

Nigeria has a critical shortage of midwives (and other skilled birth attendants) and those available usually provide care in urban clinics (see Table 1). [22, 23] This shortage limits coverage for after-hours care, and thus affects use of delivery care more than antenatal care since the latter usually occurs during regular business hours. [24-27] Midwives' attrition reduced MSS clinics' capacity to provide after-hours delivery care, and explains the level trend in use of delivery services in rural public sector clinics. [6] Midwives' attrition also increased the availability of midwives in urban areas, which may have increased the capacity of urban (public sector) clinics to provide after-hours delivery care. This may explain why we observed a level trend in use of antenatal service, a 5-percentage point increase in use of delivery services in urban public sector clinics, and a 4 percentage point reduction in deliveries occurring away from clinics (see Table 5). There are other plausible explanations for our observations. For example, it is possible that most MSS facilities were in peri-urban areas. 


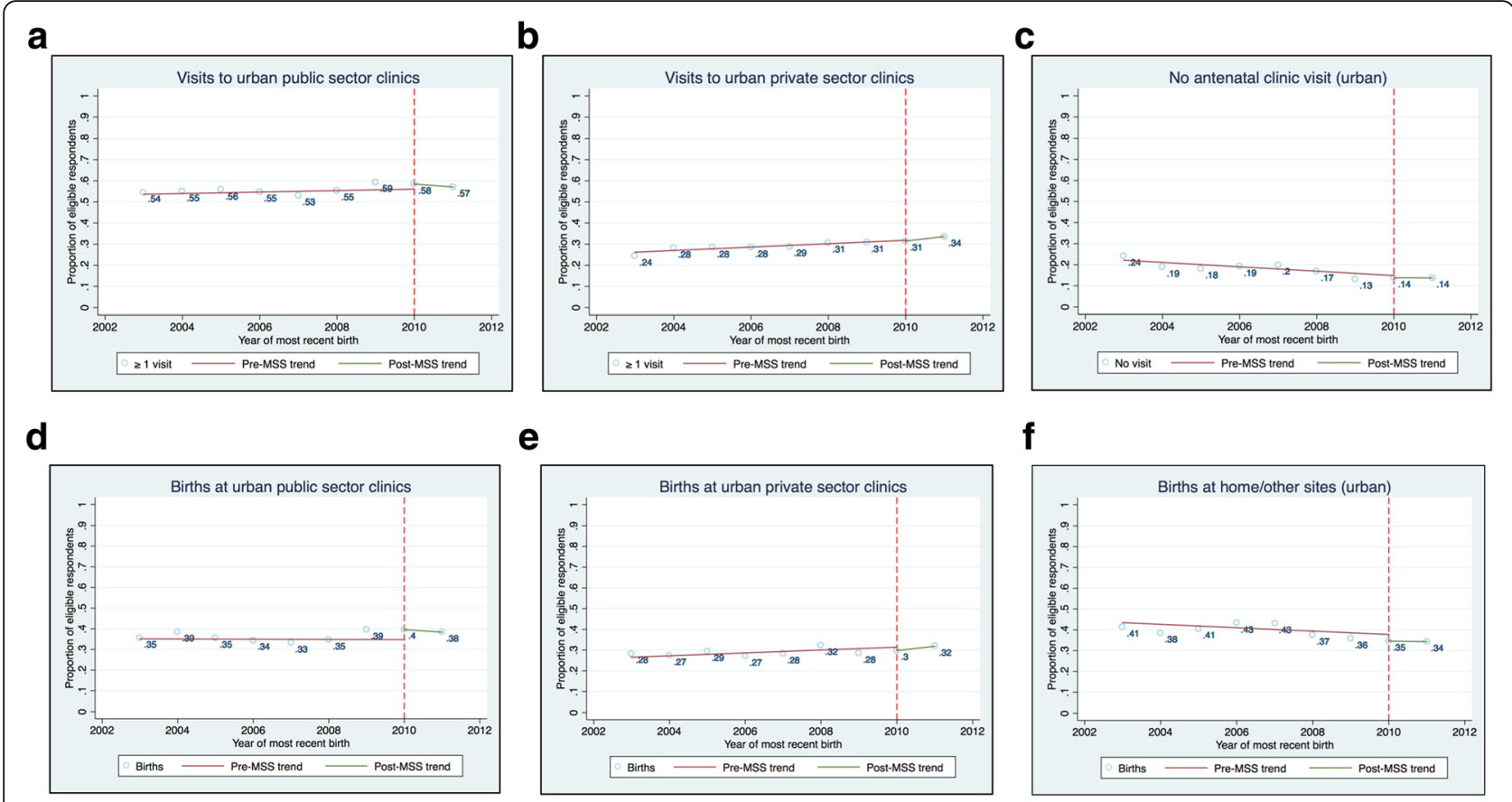

Fig. 2 Changes in obstetric care utilization in urban areas

We are unable to verify this as data on the characteristics of MSS clinics, or their selection criteria are not publicly available. However, this explanation is unlikely because the program prioritized providing greater access to women in remote and hard to reach rural areas. A second plausible explanation is that there may have been one or more concurrent state-level demand inducing maternal interventions. In exploring this possibility, we found only one concurrent state-level intervention - the Abiye project in Ondo state - which was introduced between 2009 and 2010. [28-31] However, this explanation is also unlikely for two reasons: our results didn't change when we excluded data from residents of Ondo and its neighboring states from our analyses; and Ondo state is in the South. A third plausible explanation is that the relatively faster rate of development and/or greater propensity for institutional delivery in urban areas (compared to rural areas) may have driven the increase in use of delivery services in urban clinics. However, this is unlikely for several reasons: the increase was restricted to urban public sector clinics; there was no change in antenatal clinic visits in urban clinics; when we re-centered respondents' data around 2009 and 2008, we observed no change in outcomes of interest; and our conclusions were robust when we used alternative analytic methods (i.e. difference-in-difference and difference-in-discontinuities) that allowed us control for time (either linearly or using time fixed effects).

This study has some limitations. Although potentially useful, we did not provide estimates of the scheme's
ITTE and spillover effect by zone, because such analyses might be underpowered. We used a complete case analyses approach for two reasons: less than $4 \%$ of respondents' data was missing; and we found no plausible explanation for the mechanism of missingness. We also did not assess for changes in the number of antenatal visits because between 2003 and 2013, per policy recommendation, many clinics may have switched from the traditional care model (requiring 10 - 13 antenatal visits on average) to the focused care model (requiring at least four antenatal visits on average in uncomplicated cases). [32-34] In this instance, the rate of adoption of the new model will constitute a time varying unobserved variable that would bias estimates. Lastly, some respondents that delivered in 2010 may have needed antenatal care in 2009. This could introduce measurement error and bias in our analyses. However, this is unlikely as our estimates closely match those from an earlier study. It is plausible that outcome trends in use of obstetric service are more amenable to non-linear specification. We explored this by specifying outcome trends using quadratic and cubic terms (with single trends as well as separate pre- and post trends in outcomes of interest), and we obtained similar results.

\section{Conclusion}

MSS-induced increases in use of antenatal services at rural public-sector clinics were driven by the program's intended beneficiaries. Additionally, midwife attrition from the MSS 
was associated with a spillover of the scheme's effect on the use of delivery services in urban areas.

\section{Abbreviations}

DHS: Demographic and Health Survey; ITS: Interrupted time series;

ITTE: Intention-to-treat effect; MSS: Midwives Service Scheme; NDHS: Nigerian Demographic and Health Surveys; SURE-P MCH: Subsidy Reinvestment and Empowerment Program for Maternal and Child Health

\section{Availability of data and materials}

The datasets supporting the conclusions of this article are available through the Demographic and Health Surveys website, https://dhsprogram.com.

\section{Authors' contributions}

All authors (DE, HO, CK, FB, JM, SW \& HT) made substantial contributions to conception and design of this study, acquisition of DHS data, as well as analysis and interpretation of data. All authors (DE, HO, CK, FB, JM, SW \& HT) were involved in drafting the manuscript and revising it critically for important intellectual content. All authors (DE, HO, CK, FB, JM, SW \& HT) gave final approval of the version to be published, and agreed to be accountable for all aspects of the work in ensuring that questions related to the accuracy or integrity of any part of the work are appropriately investigated and resolved.

\section{Ethics approval and consent to participate}

This is an analysis of free, publicly available secondary data, so formal ethical clearance was not needed. Permission to use and analyze the dataset was obtained by registering the project on the Demographic and Health Survey (DHS) website via http://www.measuredhs.com/accesssurveys/ access_instructions.cfm.

\section{Competing interests}

The authors declare that they have no competing interests.

\section{Publisher's Note}

Springer Nature remains neutral with regard to jurisdictional claims in published maps and institutional affiliations.

\section{Author details}

${ }^{1}$ Department of Health Policy and Management, the University of North Carolina at Chapel Hill, Chapel Hill, NC 27599, USA. University Hospitals of Leicester NHS Trust, Leicester, UK. ${ }^{3}$ Department of Obstetrics and Gynecology, University of Ibadan, Ibadan, Nigeria. ${ }^{4}$ Department of Public Policy, University of North Carolina at Chapel Hill, Chapel Hill, USA. ${ }^{5}$ Department of Medical Ethics and Health Policy, University of Pennsylvania, Philadelphia, USA

\section{Received: 12 April 2017 Accepted: 10 April 2018}

Published online: 23 April 2018

\section{References}

1. Abimbola S, Okoli U, Olubajo O, Abdullahi MJ, Pate MA. The midwives service scheme in Nigeria. PLoS Med. 2012:9(5):541.

2. Okeke EN, Glick P, Abubakar IS, Chari AV, Pitchforth E, Exley J, Bashir U, Setodji CM, Gu K, Onwujekwe O: The better obstetrics in rural Nigeria (BORN) study. 2015.

3. Okeke E, Glick P, Chari A, Abubakar IS, Pitchforth E, Exley J, Bashir U, Gu K, Onwujekwe $O$. The effect of increasing the supply of skilled health providers on pregnancy and birth outcomes: evidence from the midwives service scheme in Nigeria. BMC Health Serv Res. 2016;16(1):425.

4. About the Nigerian Midwives Service Scheme (MSS) available at http:// www.rand.org/health/projects/born/mss.html. Accessed Dec 2015.

5. Nigeria Midwives Service Scheme, written by the National Primary Healthcare Development Agency, and available at http://www.who.int/workforcealliance/ forum/2011/hrhawardscs26/en/. Accessed December 2015.

6. Ager AK, Lembani M, Mohammed A, Ashir GM, Abdulwahab A, Pinho H, Delobelle P, Zarowsky C. Health service resilience in Yobe state, Nigeria in the context of the Boko haram insurgency: a systems dynamics analysis using group model building. Confl Heal. 2015;9(1):30.
7. Uzochukwu B, Onwujekwe O, Akpala C. Community satisfaction with the quality of maternal and child health services in Southeast Nigeria. East Afr Med J. 2004:81(6):293-9.

8. Olujimi S, Ngobua S, Burlew R, Jaskiewicz W, Marsden P. Study of attrition, availability, and retention of midwife service scheme officers in Nigeria. Available at https://www.capacityplus.org/files/resources/attrition-availabilityretention-poster.pdf. In.

9. Adogu P. Midwifery and Midwives Service Scheme: A Panacea for Improvement of Some Maternal and Neonatal Indices in Nigeria-A Brief Review. Open Journal of Obstetrics and Gynecology. 2014;4(07):343.

10. Akubudike E. Midwives' and mothers' perception of midwives service scheme in Selected area councils in Federal Capital Territory. Abuja; (Doctoral dissertation). 2016.

11. Igberase G. Maternal and Foetal deaths from ruptured spleen following abdominal massage by traditional birth attendants in the Niger Delta, Nigeria. Afrimedic Journal. 2013;3(1):34-6.

12. Erim DO, Kolapo UM, Resch SC. A rapid assessment of the availability and use of obstetric care in Nigerian healthcare facilities. PLoS One. 2012;7(6):e39555.

13. Abidin SIZ, Latif $Y$, Razak BT, Latif JY. Prevalence and determinants of appropriate health seeking behaviour among known diabetics: results from a community-based survey. Advances in Epidemiology. 2014:2014:1-7.

14. Muriithi MK. The determinants of health-seeking behavior in a Nairobi slum, Kenya. Eur Sci J. 2013;9:151-64.

15. Okoli U, Morris L, Oshin A, Pate MA, Aigbe C, Muhammad A. Conditional cash transfer schemes in Nigeria: potential gains for maternal and child health service uptake in a national pilot programme. BMC pregnancy and childbirth. 2014;14(1):1.

16. ICF Macro \& National Population Commission. Nigeria demographic and health survey 2008. In: ICF Macro \& National Population Commission (2009); 2009.

17. National Population Commission \& ICF International. Nigeria demographic and health survey. Nigeria: Abuja; 2013.

18. Demographic and Health Survey Sampling and Household Listing Manual. Measure \& ICF International 2012

19. Ettarh RR, Kimani J. Influence of distance to health facilities on the use of skilled attendants at birth in Kenya. Health care for women international. 2016;37(2):237-49.

20. National Population Commission and ORC Macro. Nigeria: Demographic and Health Survey; 2003-2004

21. Commission NNP, Macro O. Nigeria demographic and health survey. In: 1999: National Population Commission; 2000.

22. Pacqué-Margolis S, Muntifering C, Ng C, Noronha S. Population growth and the global health workforce crisis. 2011. Available at https://pdf.usaid.gov/ pdf_docs/PA00HQ6B.pdf.

23. World Health Organization. The world health report 2006: working together for health. World Health Organization; 2006

24. Austin JB: A phenomenological investigation of physician job satisfaction in rural integrated primary care: Antioch university New England; 2012

25. Hart LG, Lishner DM, Johnson KE. Conclusions: rural health care workforce issues for the 21st century. In: Larson EH, Johnson KE, Norris TE, Lishner DM, Rosenblatt RA, Hart LG, editors. State of the health workforce in rural America: profiles and comparisons. Seattle: WWAMI Rural Health Research Center; 2003.

26. Ndidi E, Oseremen I. Reasons Given by Pregnant Women for Late Initiation of Antenatal Care in the Niger Delta, Nigeria. Ghana Medical Journal. 2010; 44(2):47.

27. Oladapo OT, Iyaniwura CA, Sule-Odu AO. Quality of antenatal services at the primary care level in Southwest Nigeria. Afr J Reprod Health. 2008;12(3):71-92.

28. Fajembola T. Abiye: Safemotherhood: a case of leadership in turning the tide of maternal mortality in Nigeria. Nigerian health journal. 2011;

29. Isola OO. The use of mobile telephone in reducing pre-Natal maternal mortality: case study of Abiye (safe motherhood) project in Ondo state, Southwest Nigeria. Paris: A Paper Presented at the International Conference on Habitele in University Sciences Po; 2013.

30. Love OO. Experiences of women participating in a safe motherhood (Abiye) project in Ondo state of Nigeria. Int J Curr Microbiol App Sci. 2013;2(12):148-61.

31. Cooke J, Tahir F. Maternal health in Nigeria: with leadership, progress is possible. Washington DC. In: USA: Center for Strategic and International Studies (CSIS); 2013

32. Villar J, Ba'aqeel H, Piaggio G, Lumbiganon P, Belizán JM, Farnot U, AlMazrou Y, Carroli G, Pinol A, Donner A. WHO antenatal care randomised trial for the evaluation of a new model of routine antenatal care. Lancet. 2001; 357(9268):1551-64. 
33. Carroli G, Villar J, Piaggio G, Khan-Neelofur D, Gülmezoglu M, Mugford M, Lumbiganon P, Farnot U, Bersgjø P, Group WACTR. WHO systematic review of randomised controlled trials of routine antenatal care. Lancet. 2001; 357(9268):1565-70.

34. Aniebue U, Aniebue P. Women's perception as a barrier to focused antenatal care in Nigeria: the issue of fewer antenatal visits. Health Policy Plan. 2011;26(5):423-8

35. The 2006 Nigerian census by the National Population Commission.

36. The Nigerian National Human Resources For Health Strategic Plan: 2008 to 2012.

37. Awofeso N. Improving health workforce recruitment and retention in rural and remote regions of Nigeria. Rural Remote Health. 2010;10(1):1319.

38. Ebuehi O, Campbell P. Attraction and retention of qualified health workers to rural areas in Nigeria: a case study of four LGAs in Ogun state. Nigeria Rural Remote Health. 2011;11(1):1515.

39. Dutta A, Kariisa E, Osika J, Kombe G, Johnson A, Onoja M, Oyemakinde A. The private health sector in Nigeria-an assessment of its workforce and service provision. Bethesda, MD: Health Systems. 2009;20:20.

40. National Strategic Health Developnment Plan (NSHDP) 2010 - 2015. In. The Nigerian Federal Ministry of Health. Available at http://www.health.gov.ng/ doc/NSHDP.pdf.

Ready to submit your research? Choose BMC and benefit from:

- fast, convenient online submission

- thorough peer review by experienced researchers in your field

- rapid publication on acceptance

- support for research data, including large and complex data types

- gold Open Access which fosters wider collaboration and increased citations

- maximum visibility for your research: over $100 \mathrm{M}$ website views per year

At BMC, research is always in progress.

Learn more biomedcentral.com/submissions 